\title{
Are we studying too few taxa? Insights from aphidophagous ladybird beetles (Coleoptera: Coccinellidae)
}

\author{
JOHN J. SLOGGETT* \\ Department of Animal Ecology I, Bayreuth University, Universitätstrasse 30, D-95440 Bayreuth, Germany; \\ e-mail: johnsloggett@yahoo.co.uk
}

Key words. Coccinellidae, study bias, model organism, comparative method

\begin{abstract}
Many areas of biology employ standard model organisms on which a majority of research effort is concentrated. However, there is invariably a danger associated with the use of too few or atypical models for studies of particular taxonomic groups, guilds or biological phenomena. Using aphidophagous ladybirds, I show that in this group, in the last ten years, $69 \%$ of research has been concentrated on just five species, all generalist ecotypes. Much research is now concentrated on invasive species, originally biocontrol agents, and over half the aphidophagous ladybird work on intraguild interactions is centred on two of the five predominant species, Coccinella septempunctata and Harmonia axyridis. Using examples from differing areas of research, I show that studies of more unusual, non-commercial specialists can enhance our understanding of the commonly studied groups. I suggest further areas where a similar approach may lead to equally illuminating results.
\end{abstract}

\section{INTRODUCTION}

Many areas of biology use model organisms on which the majority of research is concentrated. For example, the mouse Mus musculus, the fruit fly Drosophila melanogaster, the nematode Caenorhabditis elegans and the weed Arabidopsis thaliana have respectively become the standard mammalian, insect, lower invertebrate and plant models for geneticists and developmental biologists: most research is carried out using these organisms and they form reference points to which studies on other taxa may be compared. Usually a model organism becomes such because it is amenable and easy to use in the type of research for which it is a standard. For example, D. melanogaster has a simple four chromosome-pair genome, a short generation time, is easy to rear and is small, so can be kept in large numbers. The latter factor facilitated the discovery of mutant forms, which formed the basis of early work. However, more arbitrary historical factors also play a role. The predominance of $D$. melanogaster over other Drosophila species in genetic research is a likely result of it being the first to be brought into the laboratory: had another similar Drosophila been used first, it is probable that this would now be the standard model (Kohler, 1994).

It is clear that model organisms are necessary: we would have a much poorer understanding of the insect genome, for example, if research on insect genetics had been carried out on a diverse and arbitrary selection of insect taxa without D. melanogaster as a point of reference. But there is also a risk of overgeneralization. All insect genomes are not the same as that of Drosophila, even those of other Diptera (e.g. Gerbi, 1986). The risk of overgeneralization is particularly great in ecology, where species and interactions may differ in subtle ways that we may not necessarily appreciate; in studies of particular guilds or taxonomic groups, a few species, families or larger groupings, such as orders, may come to predominate in all work. If these are unrepresentative, and are used for generalization, spurious conclusions may come to gain a wide circulation.

In this paper, I use the aphidophagous Coccinellidae (ladybird beetles) to illustrate the potential risks of species study bias within a taxonomic group. All coccinellids are not aphidophagous; however the aphidophagous coccinellids are essentially a taxonomic group, notwithstanding the dispersed nature of aphidophagous taxa within the family (Kováŕ, 1996). They also clearly form a significant, if restricted, portion of the guild of aphidophages and have been intensively investigated. As such, they seem a suitable model group to investigate species bias in biological studies.

\section{A SURVEY OF SPECIES USED IN EXPERIMENTAL AND OBSERVATIONAL RESEARCH}

In order to examine the spread and diversity of coccinellid species in experimental and observational studies of the group, I examined published work using the Web of Science ${ }^{\circledR}$, a web-based index of scientific research papers (see http://www.isinet.com/products/citation/wos/). Two time periods were examined: from 1995 to $1^{\text {st }}$ September 2004, when the analysis was carried out, and an earlier period from 1965 to 1974 . In this way I hoped to gain some historical perspective on changes in the species used for research in the last 40 years. I used the search term COCCINELLID*, which would access all papers containing "coccinellid", including "coccinellids" and "Coccinellidae" in the title, and in the keywords and

\footnotetext{
* Present address: Department of Entomology, University of Kentucky, S-225 Agricultural Science Center North, Lexington, KY 40546-0091, USA.
} 


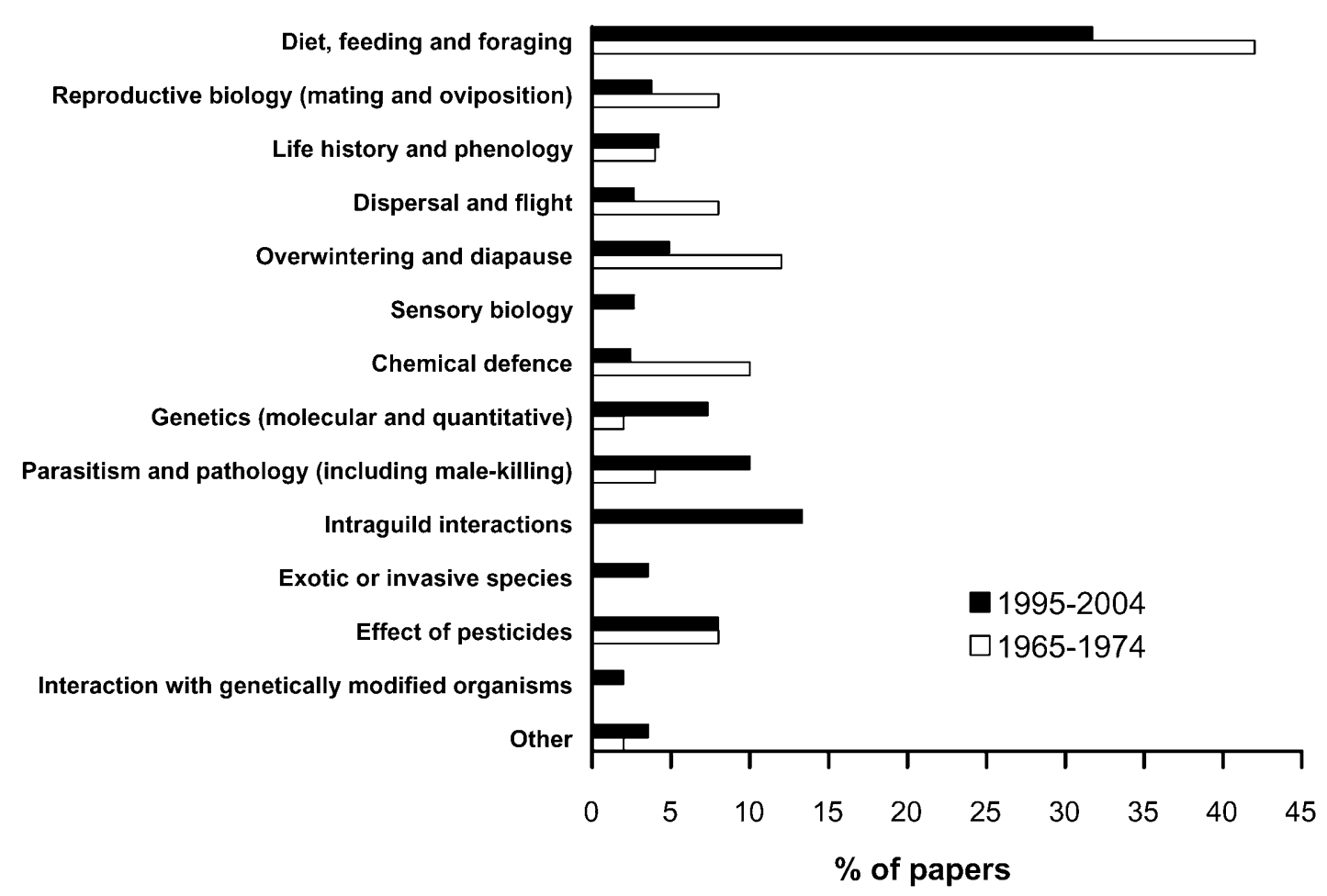

Fig. 1. Percentage of experimental and observational papers on named aphidophagous coccinellid species in different research areas for two time periods. For 1965-1974, N = 50 papers; for 1995-2004, N = 451 papers.

abstract, for the more recent period. Data from the search was categorised and processed on the basis of the title and abstract where available; in some cases where the nature of the paper was still unclear, particularly the older papers, for which abstracts were not available, I consulted the original paper.

It was necessary to further refine the datasets in order to obtain data consisting exclusively of experimental or observational studies of aphidophagous ladybirds in which I considered the choice of study species likely to be that of the researcher. I excluded papers from the original datasets that:

(1) possessed some indirect relevance to coccinellid biology, but were about other groups (e.g. Daly et al., 2000);

(2) used coccinellids as part of an experimental design but were concentrated on the biology of another organism and not on coccinellid biology (e.g. Stacey \& Fellowes, 2002);

(3) papers about non-aphidophagous ladybirds (but not papers about aphidophagous species feeding on nonaphid prey);

(4) reviews or theoretical studies;

(5) taxonomic papers, which, of necessity, include a wide range of species;

(6) checklists or surveys of coccinellids associated with particular aphid species or biotopes (e.g. Bosque-Perez et al., 2002; Poorani, 2002) - in such surveys, there is no choice of species by the researcher, and inevitably a bias towards common species which are present in most surveys;

(7) papers that considered coccinellids as a group without differentiating between species (e.g. Schmidt et al., 2003).
The remainder of papers were experimental or observational studies of aphidophagous coccinellids in which I considered the researcher had chosen the study species in question. I initially categorised these papers by subject (Fig. 1) to gain a basic picture of scientific activity in different areas of research.

For the main analysis, of the coccinellid species being studied, a more complex approach was required, as many studies were of more than a single species. I therefore considered each species in each study a single "species study" and based my species analysis on the total number of "species studies". Because this approach was used, I also excluded a very small number of papers where a single biological parameter had been measured for a very large number of species $(\geq 10)$ (e.g. Gregory et al., 2003): such papers contain very little data for a single species and potentially exert a distorting effect overall. In a few other cases, papers contained data for $\geq 10$ species, in an initial survey of a particular biological parameter, but went on to concentrate on fewer species in a more detailed study (e.g. Pasteels et al., 1973; Webberley et al., 2004): in these cases the species in the more detailed study were included in the analysis. I carried out three species analyses: one for the total species studies datasets, for both periods of time; one for species studies datasets based on papers I had previously categorised as on coccinellid diet, feeding and foraging, as categories, and one for a similar dataset on intraguild interactions. The intraguild analysis was only carried for 1995-2004, as there were no such papers in the 1965-1974 dataset.

Between 1995 and 2004 there were 451 papers giving a total of 623 species studies. There were far fewer for the period 1965-1974: 50 papers giving a total of 104 species studies. As already noted, the Web of Science ${ }^{\circledR}$ does not 
provide searchable abstracts for the earlier period; more importantly, coverage of a diversity of journals is poorer further back in time: thus the difference in numbers of papers between the two periods is without doubt exaggerated. It may reflect the "publish or die" tendency in modern science, and the tendency of researchers now to publish a larger number shorter papers on the basis of their research, but there is no evidence to support this: the Journal of Economic Entomology, which is covered by the Web of Science fully for both periods, yields nine papers, for both 1965-1974 and 1995-2004.

The papers cover a wide variety of subject matter (Fig. 1), with studies of diet, feeding and foraging predominating in both periods. However, one change is particularly notable: studies of exotic or invasive species, and (frequently associated) studies of intraguild interactions are both notably absent in the earlier period, but form, together, about $17 \%$ of papers (76 of the 451 studies) in the period 1995-2004.

What is apparent from the species analysis is the overall predominance of relatively few species. Just five species, Coccinella septempunctata, Harmonia axyridis, Adalia bipunctata, Coleomegilla maculata and Hippodamia convergens form $69 \%$ of all species studies from 1995-2004, with the first two alone forming 40\% together (Fig. 2A). The pattern is very similar if papers on feeding are considered alone (Fig. 2B). Species studies on intraguild interactions are dominated by $C$. septempunctata, with $33 \%$, and $H$. axyridis, with $19 \%$ (Fig. 2C): this no doubt reflects the recent establishment of these species in northern America and the threat which they are thought to pose to American native species.

With one exception, $H$. axyridis, the dominant species in the 1995-2004 dataset also predominate in the 1965-1974 dataset for all species studies: they form 50\% of studies compared with $51 \%$ of studies for the same four species in the 1995-2004 dataset (Fig. 2A). Thus, it does not appear that in the last forty years study preferences have greatly changed, except in the case of $H$. axyridis: for 1965-1974 there are no studies at all of this species (Fig. 2A). The cause of this difference is evidently the introduction and establishment of this species in North America, in the 1980s and 1990s, and more recently in western Europe: the predominance of $H$. $a x y$ ridis in recent studies reflects, in large part, initial interest in its biocontrol potential and latterly concern over its overwhelming competitive advantage and the various deleterious effects resulting from its establishment. They also reflect the ease with which this species may be obtained for research projects, as a consequence of its commonness. Studies of $H$. axyridis are continuing to increase: this trend can be traced across the 1995-2004 dataset, to a point where this species now features in over $40 \%$ of all papers on named species of aphidophagous coccinellid (Fig. 3).

The 1965-1974 dataset on diet, food and foraging is rather small to draw firm conclusions, only 49 species studies. It appears to show a higher diversity of species studied. Three native North American species, Coccinella novemnotata, Coccinella trifasciata (three species studies each) and Anatis mali (five species studies) have similar values to those of $C$. septempunctata (four species studies) and $H$. convergens (three species studies) (Fig. 2B). It does seem likely that as interest in exotic species has increased in America, interest in some native species with potential for natural biocontrol, such as the two Coccinella species, has declined; this is also suggested by the all-studies dataset, in which it appears studies of $H$. axyridis have increased at the expense of other species, outside of the remaining top four. However, the high value for $A$. mali, the only specialist species, is an overestimate, resulting exclusively from a series of five studies by B.C. Smith (1965a, b, c, 1966a, b), four published in the Canadian Entomologist, a journal catalogued in the Web of Science for the entire period: the limitations in the use of such a restricted dataset, in respect of journal coverage, are evident here.

Overall, however, a clear picture emerges of the overarching dominance of just five species in studies. Coccinella septempunctata, Harmonia axyridis, Adalia bipunctata, Coleomegilla maculata and Hippodamia convergens are, in many respects rather similar: they are polyphagous generalist species, they all play a significant role in biocontrol and they are common and easily obtained for research. The mere predominance of a few species in studies of aphidophagous coccinellids is not a problem in itself. The five species are studied because they are important in pest control or due to their invasive nature: a lot of these studies are targeted against specific problems; this is most evident in the case of $H$. axyridis. However, there are hundreds of aphidophagous coccinellids and many of these differ ecologically more from the predominant five than the five do from each other. A problem can arise if we generalise too far from such a narrow range of species, or fail to see the study organism in a wider context. Studies of other, different species may even throw more illuminating light on the biology of commonlystudied species: the comparative method in biology has proved to be a powerful tool, but one which may be overlooked, especially in applied research, like that for biocontrol, where there is a tendency to concentrate on specific problems, pests and control agents.

In the next two sections, I highlight work involving more specialised species, which either falsifies generalisations made from only studying a few common species, or enhances our understanding, not only of the biology of the less studied species, but the common species as well.

\section{COCCINELLA SPECIES CHEMICAL DEFENCE: A CASE OF STUDY BIAS}

Since the 1970s the alkaloid chemical defences of coccinellids have been of considerable interest to chemists and biologists, and the source of a variety of novel chemical structures (Daloze et al., 1995; King \& Meinwald, 1996). Within the highly speciose Coccinella genus, the five species studied until recently all possessed the alkaloid N-oxide coccinelline with or without its free base precoccinelline (Fig. 4). This, along with knowledge 


\section{(A) ALL STUDIES}
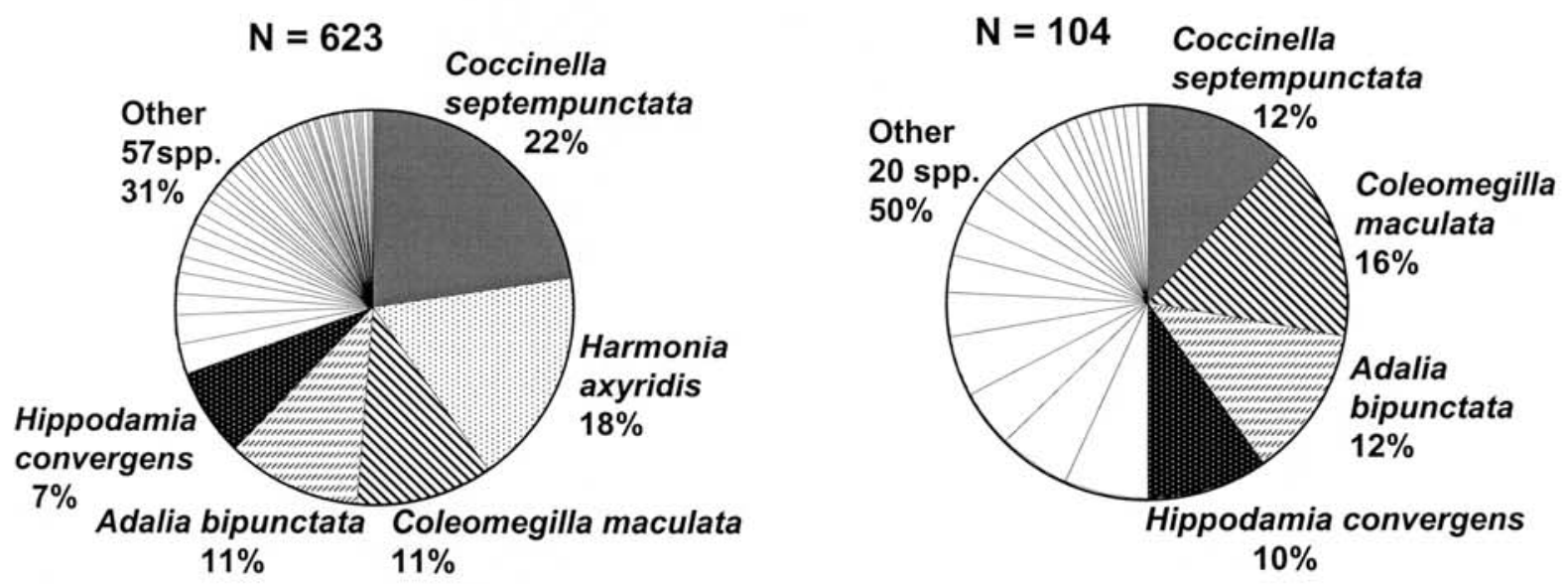

(B) DIET, FOOD \& FORAGING
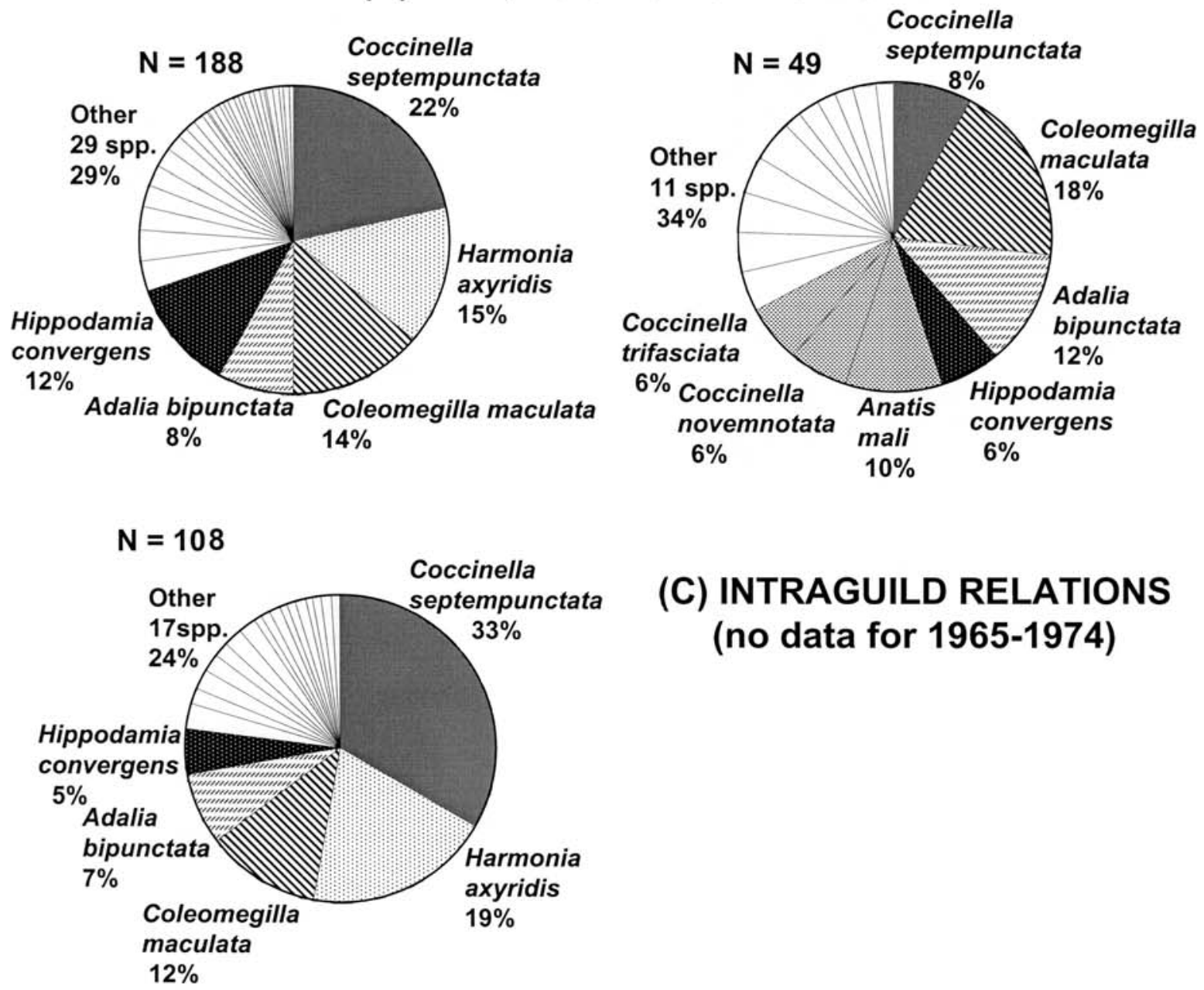
(C) INTRAGUILD RELATIONS (no data for 1965-1974)

Fig. 2. Species composition of experimental and observational studies of coccinellids during 1995-2004 (left pie charts) with older data from 1965-1974 for comparison (right pie charts). Top - all data; middle - data from papers on diet, food and foraging; bottom - data on intraguild interactions. There is no data for intraguild interactions for the older time period. For methodology, see text. 


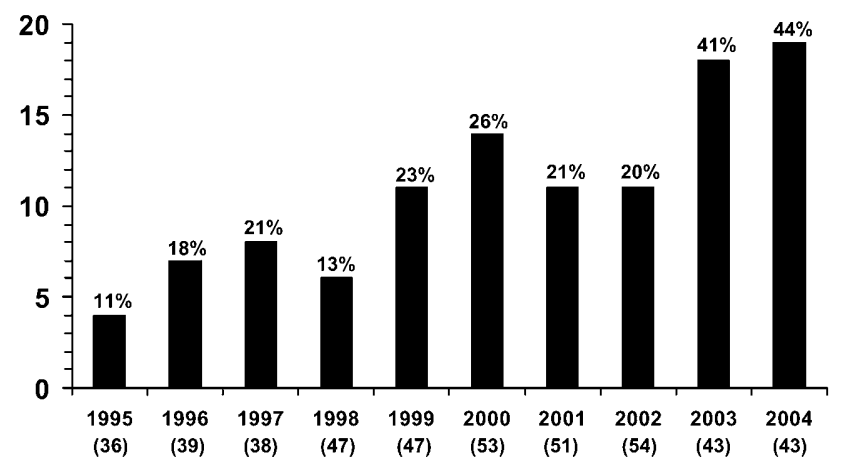

Fig. 3. The increase in experimental/observational papers published on Harmonia axyridis each year between 1995 and 2004. The bars represent the number of papers published on $H$. axyridis in a given year; in parentheses, below the year, are the total number of experimental/observational papers for that year, covering all species; the percentage values show the proportion of these papers that include $H$. axyridis as part of the study. Data for 2004 is until $1^{\text {st }}$ September.

of identical alkaloids shared by other congeners, such as Hippodamia, Adalia and Calvia species (Daloze et al., 1995; King \& Meinwald, 1996; Braekman et al., 1999) suggested that alkaloid types are highly conserved in closely related (congeneric) species. Indeed, when Coccinella magnifica $(=C$. distincta), a rarely-studied myrmecophilous species, was first found to contain, not the coccinelline and precoccinelline typical of Coccinellas, but a stereoisomer more typical of the genus Hippodamia, hippodamine (Fig. 4), Dixon (2000) questioned C. magnifica's systematic placing with other Coccinella species.

Myself and co-workers have recently found that Coccinella magnifica contains not only hippodamine but its $\mathrm{N}$-oxide convergine; another rarely-studied specialist, Coccinella hieroglyphica is devoid not only of the typical coccinelline and precoccinelline of most Coccinellas, but the convergine and hippodamine of $C$. magnifica too, and

\section{1-2000}<smiles>C[C@@H]1C[C@@H]2CCC[C@H]3CCC[C@H](C1)[N+]32[O-]</smiles><smiles>C[C@H]1C[C@H]2CCC[C@H]3CCC[C@H](C1)N32</smiles>

coccinelline (precoccinelline*)

\section{C. septempunctata* \\ C. quinquepunctata* \\ C. undecimpunctata \\ C. californica \\ C. transversoguttata*}

may possess no alkaloid defence at all (S.A. Westerlund, M. Körner \& J.J. Sloggett, unpub. data: Fig. 4). There is also good morphological and molecular genetic evidence supporting C. magnifica's phylogenetic origins and systematic placing within the Coccinella genus (IablokoffKhnzorian, 1982; Palenko et al., 2004), including our mitochondrial DNA phylogeny which contains C. magnifica, other Coccinella species and the hippodaminebearing H. convergens (G.D.D. Hurst, J.H. Schulenburg \& J.J. Sloggett, unpub. data). In fact, while most Coccinellas probably do contain coccinelline-precoccinelline defences, their apparent universality was merely an artefact of studies biased towards common, easily collected Coccinella species, which are broadly all generalist ecotypes, primarily of herbaceous habitats. The five species originally studied are all of this type (e.g. Ives, 1981; Frazer \& Raworth, 1985; Majerus, 1994; Honěk \& Hodek, 1996): they all face similar natural enemies and require similar chemical defences. When the more unusual habitat specialists, which are more difficult to collect, were studied, these were found to have different defences, which in turn arise from the different natural enemies they face in their different habitats. In the case of C. magnifica, the alkaloids of this myrmecophile are probably optimised for chemical defence used by the larvae against the ants with which it lives (see Pasteels et al., 1973; Sloggett \& Majerus, 2003); in C. hieroglyphica, it is suspected that avoidance of parasitism by the parasitoid Dinocampus coccinellae, which uses precoccinelline as a host cue, has resulted in the loss of coccinellineprecoccinelline defences (see Majerus, 1997; Al Abassi et al., 2001).

This provides a good example where the ease with which common generalists may be collected for study has resulted in a clear bias in the results obtained. Only work on the more unusual, less easily collected species has revealed this bias. In fact it seems likely that many conge-

\section{now}<smiles></smiles>

convergine hippodamine<smiles>C[C@H]1C[C@H]2CCC[C@H]3CCC[C@H](C1)N32</smiles>

\section{C. magnifica}

\section{no alkaloids (?) \\ C. hieroglyphica}

Fig. 4. Recorded alkaloids of Coccinella species ladybirds. For thirty years only the alkaloids coccinelline (from all five species studied) and precoccinelline (from asterisked species) were known from this genus. Recent studies have discovered two more specialised species without coccinelline-precoccinelline defences. Sources: Tursch et al., 1971a, b, 1975; Ayer et al., 1976; Lognay, cited in Dixon, 2000; S.A. Westerlund, M. Körner \& J.J. Sloggett, unpub. data. 
neric coccinellids do contain similar alkaloids because they live in similar habitats and face similar enemies; however there is no intrinsic constraint on alkaloid evolution and contrary to Dixon's assertion, which is tacitly implicit in many other works, closely related species may easily evolve different alkaloid defences if they face different natural enemies.

\section{ADALIA DECEMPUNCTATA: A VALUABLE SPECIALIST COMPARATOR}

The Palaearctic 10-spot ladybird, Adalia decempunctata, is the sibling species of the well-studied generalist Adalia bipunctata (Lusis, 1973; Iablokoff-Khnzorian, 1982; Palenko et al., 2004) and the two species will even produce hybrid offspring in the laboratory (Ireland et al., 1986). However, A. decempunctata is more specialised: whereas $A$. bipunctata occurs in the herbaceous layer, including crops, as well as shrubs and deciduous trees, $A$. decempunctata is largely restricted to the latter (Honěk 1985; Honěk \& Hodek, 1996; Sloggett \& Majerus, 2000). Adalia decempunctata is by no means rare in Europe, and is easily collected in large numbers from deciduous trees, along with $A$. bipunctata. However, compared with its congener, there are few studies on $A$. decempunctata; just five species studies between 1995 and 2004, compared with 67 involving $A$. bipunctata.

However, its value as a comparator for $A$. bipunctata has been demonstrated on two occasions already. In the first, Sloggett \& Majerus (2000) compared parasitoid species attacking the two ladybirds. Both the attacking parasitoid species and prevalences were similar, thus they inferred that evolutionarily changes in ladybird habitat preference and specialisation were not driven by a need for enemy free space. In the second study, of ladybird parasitism by sexually-transmitted Coccipolipus mites in central Europe, Webberley et al. (2004) compared three ladybirds parasitised by the mite Coccipolipus hippodamiae, A. bipunctata, A. decempunctata and Oenopia (= Synharmonia) conglobata. They showed that development of the mite was similar on all three species, but the much higher parasite prevalence of $C$. hippodamiae on $A$. bipunctata was a consequence of a higher mating rate per unit time in $A$. bipunctata compared to A. decempunctata and $O$. conglobata, leading to enhanced mite transmission. Although earlier authors had emphasised that $A$. bipunctata, like many ladybirds, is promiscuous (e.g. Majerus, 1994), it is now evident that A. bipunctata is highly promiscuous, even for a ladybird; this was not clear before. It may be of significance, particularly with respect to the large number of studies of sexual selection in ladybirds, overwhelmingly concentrated on A. bipunctata, over the last quarter-century or so (e.g. Muggleton, 1979; Majerus et al., 1982, 1986; Brakefield, 1984; Kearns et al., 1992; de Jong et al., 1998; Webberley et al., 2002).

A case in which observations from $A$. decempunctata indicate non-universality of results from a generalist species, albeit not A. bipunctata, is that of oosorption in response to prey absence. Potentially the resorption of eggs could be of some importance in coccinellid dispersal and reproduction in the context of ephemeral aphid prey (Evans, 2003), but until recently there had been no studies examining this in coccinellids. Osawa (2005) has now shown that oosorption occurs in Harmonia axyridis in response to short periods of starvation, as might occur during dispersal between patches of aphid prey. Nonetheless, this should not be seen as universally applicable to all aphidophagous coccinellids. It remains a single study of a broad generalist; generalists are overall probably rather intolerant of low prey densities and consequently disperse frequently (Sloggett \& Majerus, 2000). Adalia decempunctata, does not apparently display oosorption (A.F.G. Dixon, pers. comm.): as this species is more specialised, more tolerant of low prey densities and probably disperses less frequently (Honěk, 1985; Sloggett \& Majerus, 2000), the, albeit limited, evidence from $H$. axyridis and $A$. decempunctata together suggests that the occurrence of this type of oosorption varies interspecifically with differences in coccinellid ecology and dispersal potential. It seems unlikely that such oosorption is of universal occurrence, although the five best-studied species, all generalists, are likely to display it.

\section{CONCLUSIONS}

In the examples given above, both the dangers of overgeneralization and of failing to ground results in a wider context are evident. The examples given reflect the interests and experience of the author, but arguably other areas will exhibit similar biases or failures of context, and require broader study bases. For example, a more rigorous examination of the intraguild interactions in natural coevolved non-crop based systems might yield interesting results, which ultimately may provide a clearer context for understanding the mode of action of invasive species, even the very well-studied Coccinella septempunctata and Harmonia axyridis.

Similarly, population genetic studies of aphidophagous ladybirds have been exclusively concentrated on generalists, particularly A. bipunctata (e.g. Lusis, 1947; Krafsur et al., 1996; Morjan et al., 1999; Obrycki et al., 2001; Haddrill et al., 2002), with the consequence that it appears that aphidophagous coccinellids invariably display high gene flow and genetic variability, and strong inbreeding depression. It is by no means clear that these results would hold for more sedentary specialists, which may less frequently form panmictic populations with unlimited gene flow.

Specialised aphidophagous coccinellids have remained largely the provenance of the naturalist or pure academic researcher. However, the high tolerance of low prey densities, low vagility, and potentially limited inbreeding effects, important in breeding programmes, may make specialists of significant biocontrol utility in particular agroecosystems, such as forests or rice paddies: there is already limited evidence that this is so (Goidanich, 1943; Leather \& Kidd, 1998; Berthiaume et al., 2000).

Beyond specific biological questions, there is also an issue of taxonomic bias. The examples discussed in this 
paper relate exclusively to one aphidophagous group, the tribe Coccinellini. These are the largest and most charismatic group of coccinellids. Other groups, such as the Scymnini, are much less researched. Just 15 of the 623 species studies, 2.4\%, from 1995-2004 involved the widespread and speciose genus Scymnus, although genera such as Scymnus may possess biocontrol potential. The bias arises, at least in part, because due to small size and unspectacular colouration they are harder to identify. More broadly still, amongst aphidophagous predators, coccinellids are studied much more than either chrysopids or syrphids, for example. At the 2004 Ecology of Aphidophaga 9 conference, of the 50 presentations clearly concentrated on one group, $36(72 \%)$ were on coccinellids, seven $(14 \%)$ on syrphids, two $(4 \%)$ on chrysopids and five $(10 \%)$ were on other groups.

A number of objections may be raised to the approach that has been taken here. Well-understood research models are as necessary for aphidophagous coccinellids as for other groups. However, it is the range of model species currently used that I contend is too narrow, and especially specialists may provide valuable insights into the whole group. It is true that many of these species have less practical use, for example for biocontrol (but see above) and are much less likely to attract funding, the key arbiter of what is and is not studied. However, routes to funding can be found. There is virtually no current research on the conservation biology of aphidophagous insects, beyond that related to invasive species; such work would facilitate the study of rarer, more unusual species, and might pay dividends beyond its obvious aims.

Similar biases undoubtedly occur with respect to other taxonomic groups, guilds or ecological phenomena. As already shown, studies of coccinellids predominate over other aphidophagous insects. Similarly, there have been numerous studies of metapopulation structure using Lepidoptera, far fewer using Coleoptera and just a handful using Homoptera over the last decade (source: Science Citation Index ${ }^{\circledR}$ ).

In conclusion, we should be aware of taxon- and other forms of study-bias when making generalisations, from our own studies and those of others. Model organisms are important; they form the bedrock for all research. But, especially in ecology, we should not restrict ourselves to too few models or we will fail to fully comprehend what is occurring in the real world.

ACKNOWLEDGEMENTS. I wish to thank A. Anand for the interesting discussions on model organisms that provided the original impetus for this work; A. Davis, G. Hurst and F. Jiggins for their comments on Drosophila melanogaster; G. Hurst, M. Körner, H. Schulenburg and S. Westerlund for their invaluable contributions to the research described on Coccinella alkaloids and the Deutsche Forschungsgemeinschaft for part-funding that work through the Graduiertenkolleg 678, "Ecological Significance of Natural Compounds and other Signals in Insects - from Structure to Function". I also wish to thank A. Dixon, H. van Emden, F. Gilbert, M. Majerus, J.P. Michaud, O. Nedvěd, J. Obrycki, J. Pettersson and E. Schwartzberg for their comments on my presentation at Aphidophaga 9, which have done so much to improve this paper, and P. de Jong and an anonymous referee for additional useful observations.

\section{REFERENCES}

Al Abassi S., Birkett M.A., Pettersson J., Pickett J.A., WadHAMS L.J. \& Woodcock C.M. 2001: Response of the ladybird parasitoid Dinocampus coccinellae to toxic alkaloids from the seven-spot ladybird, Coccinella septempunctata. J. Chem. Ecol. 27: 33-43.

Ayer W.A., Bennett M.J., Browne L.M. \& Purdham J.T. 1976: Defensive substances of Coccinella transversoguttata and Hippodamia caseyi, ladybugs indigenous to western Canada. Can. J. Chem. 54: 1807-1813.

Berthiaume R., Hébert C. \& Cloutier C. 2000: Predation on Mindarus abietinus infesting balsam fir grown as Christmas trees: the impact of coccinellid larval predation with emphasis on Anatis mali. BioControl 45: 425-438.

Bosque-Perez N.A., Johnson J.B., Schotzko D.J. \& Unger L. 2002: Species diversity, abundance, and phenology of aphid natural enemies on spring wheats resistant and susceptible to Russian wheat aphid. BioControl 47: 667-684.

Braekman J.-C., Charlier A., Daloze D., Heilporn S., Pasteels J., Plasman V. \& Wang S. 1999: New piperidine alkaloids from two ladybird beetles of the genus Calvia (Coccinellidae). Eur. J. Org. Chem. 1999: 1749-1755.

BRAKEFIELD P.M. 1984: Selection along clines in the ladybird Adalia bipunctata in the Netherlands: a general mating advantage to melanics and its consequences. Heredity 53: 37-49.

Daloze D., Braekman J.-C. \& Pasteels J.M. 1995: Ladybird defence alkaloids: structural, chemotaxonomic and biosynthetic aspects (Col.: Coccinellidae). Chemoecology 5/6: 173-183.

Daly J.W., Garraffo H.M., Jain P., Spande T.F., Snelling R.R., JaRAMILLO C. \& RAND A.S. 2000: Arthropod-frog connection: Decahydroquinoline and pyrrolizidine alkaloids common to microsympatric myrmicine ants and dendrobatid frogs. J. Chem. Ecol. 26: 73-85.

Dixon A.F.G. 2000: Insect Predator-Prey Dynamics: Ladybird Beetles and Biological Control. Cambridge University Press, Cambridge, $268 \mathrm{pp}$.

Evans E.W. 2003: Searching and reproductive behaviour of female aphidophagous ladybirds (Coleoptera: Coccinellidae): a review. Eur. J. Entomol. 100: 1-10.

Frazer B.D. \& Raworth D.A. 1985: Sampling for adult coccinellids and their numerical response to strawberry aphids (Coleoptera: Coccinellidae, Homoptera: Aphididae). Can. Entomol. 117: 153-161.

GERBI S.A. 1986: Unusual chromosome movements in sciarid flies. In Hennig W. (ed.): Germ Line - Soma Differentiation. Results and Problems in Cell Differentiation. Vol. 13. Springer-Verlag, Berlin, pp. 71-104.

Gregory T.R., HonĚK O. \& AdAmowicz S.J. 2003: C-value estimates for 31 species of ladybird beetles (Coleoptera: Coccinellidae). Hereditas 139: 121-127.

GoIDANICH A. 1943: Due coccinelle igrofile e pollinivore sil riso. Risocoltura 32: 145-156, 169-177 (in Italian).

Haddrill P.R., Majerus M.E.N. \& MaYes S. 2002: Isolation and characterization of highly polymorphic microsatellite loci in the 2-spot ladybird, Adalia bipunctata. Mol. Ecol. Notes 2: 316-319.

HoNĚK A. 1985: Habitat preferences of aphidophagous coccinellids (Coleoptera). Entomophaga 30: 253-264.

HoNĚK A. \& Hodek I. 1996: Distribution in habitats. In Hodek I. \& Honěk A.: Ecology of Coccinellidae. Kluwer Academic Publishers, Dordrecht, pp. 95-141. 
IABLoKoff-Khnzorian S.M. 1982: Les Coccinelles. ColéoptèresCoccinellidae. Tribu Coccinellini des régions Palearctique et Orientale. Société Nouvelle des Éditions Boubée, Paris, 568 pp.

Ireland H., Kearns P.W.E. \& Majerus M.E.N. 1986: Interspecific hybridisation in the Coccinellidae: some observations on an old controversy. Entomol. Rec. J. Var. 98: 181-185.

Ives P.M. 1981: Estimation of coccinellid numbers and movement in the field. Can. Entomol. 113: 981-997.

Jong DE P.W., Brakefield P.M. \& GeERINCK B.P. 1998: The effect of female mating history on sperm precedence in the two-spot ladybird, Adalia bipunctata (Coleoptera, Coccinellidae). Behav. Ecol. 9: 559-565.

Kearns P.W.E., Tomlinson I.P.M., Veltman C.J. \& O’Donald P. 1992: Non-random mating in Adalia bipunctata (the 2-spot ladybird). 2. Further tests for female mating preference. Heredity 68: 385-389.

King A.G. \& Meinwald J. 1996: Review of the defensive chemistry of Coccinellids. Chem. Rev. 96: 1105-1122.

KoHLER R.E. 1994: Lords of the Fly: Drosophila Genetics and the Experimental Life. University of Chicago Press, Chicago \& London, $321 \mathrm{pp}$.

KovÁŘ I. 1996: Phylogeny. In Hodek I. \& Honěk A.: Ecology of Coccinellidae. Kluwer Academic Publishers, Dordrecht, pp. 19-31.

Krafsur E.S., Nariboli P. \& Obrycki J.J. 1996: Gene flow and diversity at allozyme loci in the twospotted lady beetle (Coleoptera: Coccinellidae). Ann. Entomol. Soc. Am. 89: 410-419.

LEATHER S.R. \& KidD N.A.C. 1998: The quantitative impact of natural enemies and the prospect for biological control. In Day K.R., Halldórsson G., Harding S. \& Straw N.A. (eds): The Green Spruce Aphid in Western Europe: Ecology, Status, Impacts and Prospects for Management. Forestry Commission Technical Paper 24, Forestry Commission, Edinburgh, pp. 61-70.

Lusis YA.YA. 1947: Some rules of reproduction in Adalia bipunctata L. 1. Heterozygosity of lethal alleles in populations. Doklady Akademii Nauk SSSR 57: 825-828 (in Russian).

Lusis YA.YA. 1973: Taxonomical relationships and geographical distribution of forms in the ladybird genus Adalia. Petera Stuckas Latvijas Valsts Universitates Zinatniskie Raksti 184: 1-123 (in Russian, with English abstr.).

MaJerus M.E.N. 1994: Ladybirds. New Naturalist Series no. 81, HarperCollins, London, $367 \mathrm{pp}$.

MaJerus M.E.N. 1997: Parasitization of British ladybirds by Dinocampus coccinellae (Schrank) (Hymenoptera: Braconidae). Br. J. Entomol. Nat. Hist. 10: 15-24.

Majerus M.E.N., O'Donald P. \& Weir J. 1982: Evidence for preferential mating in Adalia bipunctata. Heredity 49: 37-49.

Majerus M.E.N., O’Donald P., Kearns P.W.E. \& Ireland H. 1986: The genetics and evolution of female choice. Nature 321: $164-167$.

MorJan W.E., Obrycki J.J. \& Krafsur E.S. 1999: Inbreeding effects on Propylea quatuordecimpunctata (Coleoptera: Coccinellidae). Ann. Entomol. Soc. Am. 92: 260-268.

Muggleton J. 1979: Non-random mating in populations of polymorphic Adalia bipunctata. Heredity 42: 57-65.

Obrycki J.J., Krafsur E.S., Bogran C.E., Gomez L.E. \& Cave R.E. 2001: Comparative studies of three populations of the lady beetle predator Hippodamia convergens (Coleoptera: Coccinellidae). Fla Entomol. 84: 55-62.

OsAwA N. 2005: The effect of prey availability on ovarian development and oosorption in the ladybird beetle Harmonia axyridis (Coleoptera: Coccinellidae). Eur. J. Entomol. 102: 503-512.
Palenko M.V., Mukha D.V. \& Zakharov I.A. 2004: Intraspecific and interspecific variation of the mitochondrial gene of cytochrome oxidase I in ladybirds (Coleoptera: Coccinellidae). Rus. J. Genet. 40: 148-151.

Pasteels J.M., Deroe C., Tursch B., Braekman J.C., Daloze D. \& Hootele C. 1973. Distribution et activités des alcaloïdes des coccinelles. J. Insect Physiol. 19: 1771-1784 (in French, with English abstr.).

PoORAnI J. 2002: An annotated checklist of the Coccinellidae (Coleoptera) (excluding Epilachninae) of the Indian subregion. Orient. Insects 36: 307-383.

Schmidt M.H., Lauer A., Purtauf T., Thies C., Schaefer M. \& TSCHARNTKE T. 2003: Relative importance of predators and parasitoids for cereal aphid control. Proc. R. Soc. Lond. (B) 270: 1905-1909.

Sloggett J.J. \& MaJerus M.E.N. 2000: Habitat preferences and diet in the predatory Coccinellidae (Coleoptera): an evolutionary perspective. Biol. J. Linn. Soc. 69: 63-88.

Sloggett J.J. \& Majerus M.E.N. 2003: Adaptations of Coccinella magnifica Redtenbacher, a myrmecophilous coccinellid, to aggression by wood ants (Formica rufa group). II. Larval behaviour, and ladybird oviposition location. Eur. J. Entomol. 100: $337-344$.

Sмiтн B.C. 1965a: Growth and development of coccinellid larvae on dry foods (Coleoptera: Coccinellidae). Can. Entomol. 97: 760-768.

Sмiтн B.C. 1965b: Effects of food on longevity, fecundity and development of adult Coccinellids (Coleoptera: Coccinellidae). Can. Entomol. 97: 910-919.

SMITH B.C. 1965c: Differences in Anatis mali Auct. and Coleomegilla maculata lengi Timberlake to changes in quality and quantity of larval food (Coleoptera: Coccinellidae). Can. Entomol. 97: 1159-1166.

Sмiтн B.C. 1966a: Variation in weight, size and sex ratio of coccinellid adults (Coleoptera: Coccinellidae). Can. Entomol. 98: 639-644.

Sмітн B.C. 1966b: Effects of food quality and age on larval activities of Anatis mali Auct. (Coleoptera: Coccinellidae). Can. J. Zool. 44: 251-255.

Stacey D.A. \& Fellowes M.D.E. 2002: Influence of temperature on pea aphid Acyrthosiphon pisum (Hemiptera: Aphididae) resistance to natural enemy attack. Bull. Entomol. Res. 92: 351-357.

Tursch B., Daloze D., Dupont M., Pasteels J.M. \& Tricot M.-C. 1971a: A defense alkaloid in a carnivorous beetle. Experientia 27: 1380-1381.

Tursch B., Daloze D., Dupont M., Hootele C., Kaisin M., PasTeels J.M. \& Zimmermann D. 1971b: Coccinellin, the defensive alkaloid of the beetle Coccinella septempunctata. Chimia 25: 307-308.

Tursch B., Daloze D., Braekman J.C., Hootele C. \& Pasteels J.M. 1975: Chemical ecology of arthropods-X. The structure of myrrhine and the biosynthesis of coccinelline. Tetrahedron 31: $1541-1543$.

Webberley K.M., Hurst G.D.D., Buszko J. \& Majerus M.E.N. 2002: Lack of parasite-mediated sexual selection in a ladybird/sexually transmitted disease system. Anim. Behav. 63: $131-141$.

Webberley K.M., HuRst G.D.D., Husband R.W., Graf von DeR Schulenburg J.H., Sloggett J.J., Isham V., Buszko J. \& Majerus M.E.N. 2004: Host reproduction and a sexually transmitted disease: causes and consequences of Coccipolipus hippodamiae distribution on coccinellid beetles. J. Anim. Ecol. 73: 1-10.

Received January 6, 2005; revised and accepted April 20, 2005 